FACTA UNIVERSITATIS

Series: Economics and Organization Vol. 17, N ${ }^{\circ} 1,2020$, pp. 43 - 56

https://doi.org/10.22190/FUEO190727004B

Original Scientific Paper

\title{
THE CROWDING-OUT EFFECT OF FISCAL POLICY ON CAPITAL INFLOWS IN NIGERIA
}

\author{
UDC 336.02(669)
}

\section{Abdurrauf Babalola, Saidat Oluwatoyin Onikosi-Alliyu}

Alhikmah University, Department of Economics, Ilorin, Nigeria

\begin{abstract}
The study investigated the effect of fiscal policy on crowding out capital inflows in Nigeria using annual data between 1970 and 2011 by using the foreign direct investment (FDI) as proxy to capital inflows represent the dependent variable, budget deficit $(B D)$, foreign borrowing $(F L)$ and domestic borrowing $(D L)$ as proxies to fiscal policy are placed as explanatory variables. Cointegration and ECM technique were employed. Our finding showed that in both the short and long run, BD does not crowd out but rather crowd in FDI. In the short run, DL averagely has significant positive impact on FDI. However, in the long run, DL has significant negative impact on FDI. More so, in both short run and long run period, FL has significant negative impact on FDI, therefore, FL crowds out FDI. The speed of adjustment back to equilibrium showed that the explanatory variables have capacity to adjust FDI significantly. The study recommends that the government could try to be aware of the implication of its fiscal policy in running a budget deficit and making proper decision in sourcing for funds to finance the deficit. Foreign borrowing is less expensive in financing budget deficit, so if the government must borrow, it should give preference to this source. Generally, the government should reduce deficit because of the implications inherent in it.
\end{abstract}

Key words: FDI, budget deficit, foreign borrowing, domestic borrowing

JEL Classification: B22, B23, C22, E62, H62

\section{INTRODUCTION}

Prior to the great depression in the 1930s, nearly all economies were operating a classical theory of no intervention of government in economic activities except to maintain law and order. Keynesian ideas were given prominence during this severe economic recession which

Received July 27, 2019 / Revised January 16, 2020 / Accepted January 22, 2020

Corresponding author: Abdurrauf Babalola

Alhikmah University, Department of Economics, PMB 1601 Ilorin, Kwara State, Nigeria

E-mail: abdclement@yahoo.com 
started from the United States, as the Classicals could not find any lasting solution to the depression which rocked the advanced economies. Keynes (1936) brought the idea that the government intervention (through fiscal policy) is necessary to boost aggregate consumption and revamp the economy back to recovery. This idea was adopted and it gave solution to the economic crisis. Also, after the global economic meltdown between 2008 and 2009, the use of expansionary fiscal policy such as increase of government expenditure and decrease of taxation to push the economy forward has been on the increase most especially in developed and developing countries. This is contrary to the prediction of both Keynesian model for a non-open economy and Mundel-Fleming proposition of a small open economy (Fleming, 1962, Mundell, 1963 and Bhaduri, 2002). This reaction has therefore sparked up a re-newed interest of many economists to the effect of expansionary fiscal policy with respect to capital mobility into an economy, especially foreign direct investment (FDI).

According to Keynesian economists, discretionary fiscal tools can be employed to influence the aggregate demand through its effect on disposable income. However, the multiplier effect will be reduced because of the crowding out effect on private investors. The theory postulated that the higher the level of openness of a nation is, the less significant the effect of fiscal tools. This theory was extended by Mundell-Fleming model to a small open economy where an inverse relationship between fiscal policy and output or employment was also established.

While the advocates of government intervention through fiscal policy say, it will boost and bring back the economy to recovery, the contenders, most especially the Monetarists, believe that it will crowd-out the participation of private investors nationally and internationally since it will affect the interest rates of investing. Fiscal deficit in Nigeria is mostly financed in two ways, through either domestic borrowing or foreign borrowing. Monetarists judge that, due to easing fiscal policy through spending increase, the government would necessarily obtain loan through sale of government bonds, which would push up interest rates in the financial market, and thus result in high cost of borrowing which 'crowds out' private investment in the same market.

Since the Nigerian government is a mixed economic system with both government and private participation, the main question is, which of the two ways of financing budget deficit will have less effect on capital mobility (direct investment) into Nigeria? Should the government incur budget deficit going by crowding out effect? In perfect capital mobility situation, fiscal policy amplification would result in increase in both income and rate of interest especially in a small open nation. Therefore, exchange rate of the home nation appreciates, thereby reducing the effect of fiscal stimulus. Besides, under a fixed exchange rate system, the effect of fiscal rule is positively felt when there is perfect capital movement. This is because perfect capital mobility enhances domestic fiscal policy since interest rate cannot rise. As a result, there will be no possibility for crowding out private investors. However, since the Nigerian economy only practices guided floating system, the argument remains on which is a better way of getting funds to finance fiscal deficit. Three ways could be employed to finance this deficit. First is through tax increase, which tends to cut down disposable income of individuals as well as corporate bodies, reduce savings and then reduce the aggregate demand of the economy which could discourage investment and make employers of labour lay off workers. Second is through money finance (seignior-age) by printing more money whose consequence is majorly inflation induced, especially if it is not during recession according to Keynes (1936). This method is seldom employed by most 
economies because of its inherent and conspicuous consequence. Third is through borrowing from foreign or domestic sources. This means is used by most economies and Nigeria. This is done when the government sells bond to private investors through the central bank to raise funds. The consequence is that the private investors, who buy these government bonds would be left with less capital for further investment in private quarter and hence, government borrowing through this means, would have crowded out private investment. It also has its implication on interest rate hike as explained earlier.

In the present day economy where financial integration of economies is very high because of the globalization process, economists have questioned the size of fiscal multiplier in both boom and recession periods (Barro, 2009), however, there is no consensus among economists. In Nigeria, the research on monetary policy and capital mobility is more pronounced than relationship of capital mobility and fiscal policy. Many researchers on fiscal policy focused on the implication it has on economic growth without considering the degree of capital mobility. Therefore, this effort is aimed at studying the impact of fiscal policy, proxy of fiscal borrowing, on capital mobility in Nigeria.

The paper is ordered as follows: Second section highlights the relevant literature. The third section discusses the model specification and a full description of the dataset. The fourth section analyses data and results of findings. The fifth section showcases conclusion and policy implications.

\section{REVIEW OF RELEVANT LITERATURE}

\subsection{Conceptual Review}

One of the major policies usually utilized for stabilization in an economy is fiscal policy. This is the use of government expenditure and revenue to regulate the economy in order to achieve a predetermined macroeconomic objective. It is usually referred to as aggregate effect of the budget result on economic activities. Fiscal policy can either be expansionary (easing) or contractionary (tightening). It is easing when government expenditure exceeds tax revenue, in which case, the government runs a budget deficit. Also, fiscal policy is tightening when tax revenue is more than government expenditure. This refers to budget surplus situation. When a government plans to spend more than it collects in taxes, it borrows to finance the deficit. The accrual of past borrowing is the government debt (Bhaduri, 2002).

The effect of expansionary fiscal policy on aggregate can be viewed from two channels in a closed economy. Firstly, the rise in public spending would exactly raise aggregate demand directly. Secondly, reduction in tax would affect consumers by increasing their disposable income which would consequently increase their aggregate demand. The investors, as well, would have a robust profit because of reduction in tax and consequent increase in demand. This could mean that government would sponsor the excess by borrowing via the sales of bonds. The action of borrowing through sale of bond would lead to rise in interest rate and consequently "crowd out" a number of personal investment i.e. reduce the portion of yield generated by private investment. The government could also borrow through obtaining loan from international community or print new notes. Each of these means has its peculiar economic implication to the system.

In an open economy, expansionary fiscal policy would reduce national savings through its impact on the exchange rate as well as trade balance. For example, government deficit 
financing leads to increased domestic rates of interest which will in turn attract foreign capital and consequently cause local currency to appreciate. Increase in the value of local currency would result to cheaper imported goods in home country. However, the country's exports become dearer outside its shores, leading to a decrease in merchandise trade balance negative net export.

Crowding out, according to Jhingan (2004), means decrease in private capital spending due to increase in public expenditure via deficit budget through a tax cut, increased money supply or issuance of public bond. Bhaduri (2002) defines it as the decrease in investment that is triggered when expansionary fiscal policy increases the rate of interest.

Capital mobility, which in this study is FDI, "is the flow of funding provided by an investor or a lender to establish or acquire a foreign company or to expand or finance an existing foreign company that the investor owns and controls" (Pugel, 2012:345).

The FDI is quite different from foreign portfolio investment which denotes all foreign securities investments which do not involve management control. FDI is a capital expenditure in a business by an investor from other country for which the foreign investor has power over the company bought. According to CBN (2017), FDI is a type of cross-border investment connected with a resident in one economy having command or a significant degree of impact on the management of a venture that is inhabitant in another economy. Businesses that make FDI are known as Multinational Corporations (MNCs) or Multinational Enterprises (MNEs).

\subsection{Theoretical Review}

Fiscal policy is based on the hypothesis of a British economist, John Maynard Keynes, whose followers are also referred to as the Keynesian economists. This hypothesis states that governments could stabilise the economy through adjusting tax revenue and government expenditure. According to this theory, increase in government spending or reduction in tax usually referred to as budget deficit, will stimulate aggregate demand especially during recession, while reduction in government expenditure and rise in tax usually called government surplus, will ensure adequate control on aggregate- demand and price stability during the boom period (Bhaduri, 2002).

There is variance of opinion between the Keynesians and Monetarists about budget deficit on the crowding out effect. The main difference between the two arises from the fact that the Keynesians emphasise on short run and partial effect, whereas the Monetarists emphasise on the long run and ultimate effect. The Keynesian crowding out effect states that, when the government resorts to deficit financing by issuing new bonds, spending increases, and national income rises. If the money supply is held constant, people will need more for business which will raise the rate of interest. This will reduce the involvement of private investors to invest as interest rates have gone up.

The Monetarists emphasise the ultimate effects of budget deficit by taking account of wealth effect. When the government expands its spending by selling bonds in the financial market, their buyers feel themselves wealthier than before, as a result, they tend to demand for money which increases their demand.

Moreover, the work of Fleming (1962) and Mundell (1963) formed the pioneer studies on the effectiveness of stabilization policy on capital mobility. The researchers explained that there is a constraint effect of fiscal policy based on the degree of capital mobility. More so, their study established that fiscal policy was negatively connected to the extent of perfect capital movement. Specifically, in a micro economy with floating exchange rate, an 
expansionary fiscal policy results in an increase in the local interest rate. This will result in rise in capital inflow (FDI) which raises the exchange rate, thereby reducing export and increasing imports and hence reducing aggregate demand. Therefore, the potency of fiscal policy is reduced. However, if the system operates a fixed exchange rate, the amount of capital movement will enhance the effect of fiscal policy.

In addition, Han (2014) extended the assumption of Mundell-Fleming's model and discussed the effectiveness of fiscal policy in a big open economy in a separate capital movement scenario. The study concluded that, in a situation of complete capital mobility, fiscal policy is physically powerful in a flat exchange rate, but not at all in a flexible exchange rate. On the other hand, when an economy has a non-perfect capital mobility, fiscal policy is physically powerful both in fixed as well as flexible exchange rate. When it comes to capital immobility, fiscal policy is less effective in a fixed exchange rate although it is strong under floating exchange rate.

Yeung-Nan, (2015) established the theoretical proposition that fiscal policy can be used to stimulate domestic output by extending Romer's IS-MP model. He replaced the LM curve in the Mundell-Fleming model with monetary reaction function. He therefore claimed that fiscal policy is effective in altering output in a floating exchange rate with perfect capital mobility.

Another major theory that discusses the effect of fiscal policy is the Ricardian equivalence hypothesis. The theory recommends that when a government tries to resuscitate by escalating debt-financed government expenditure, aggregate demand remains unaffected. It explained that the consumer behaviour is the same, regardless of the means of financing the deficit either through taxes or debt. They clearly explained that consumers are futuristic and so consumption is not a function of current income alone (Bhaduri, 2002). They did not believe in crowding in or out of fiscal policy. Pierzioch (2004) argued that fiscal policy could be efficient in a standard new open macro-economy model (NOEM). He buttressed his argument by using algorithm method for the NOEM model. After calibration of the model, he concluded that more capital movement would diminish the efficacy of fiscal policy.

In theory, an important question is how much crowding out effect happens in an economy? Economists say it depends on the economic condition of the economy. Keynes (1936) is of the opinion that if the economy is in recession like that of the great depression, crowding out does occur less since banks have savings to lend but few investors to borrow. The degree of crowding out also depends on the quantity of private savings and inflows of foreign financial investment.

\subsection{Empirical Review}

Rose (1994) examined the adjustment that exists among exchange rate, monetary policies and capital movement usually referred to as unfeasible "holy trinity". Panel data set was used for twenty-two countries. Capital mobility variable was generated from different indicators using factor analysis. Conditional exchange rate volatility was used in capturing fixed exchange rate while flexible and rigid price monetary models was used to measure the difference in monetary policies. The study showed that the fundamental macroeconomic instability and the extent of capital mobility have impact on exchange rate precariousness. Nevertheless, they explained that the study further showed that the evidence is a function of the exact gauge of monetary fundamental as being weak. 
Hsing, (2005) empirically tested the alternative macroeconomic model of Yeing-Nan (2015). He used the extended IS-MP replica to study the short-run production function in Germany. The work demonstrated that the balance gross domestic product in the country is directly connected to stock market realisation and real exchange rate appreciation, and conversely affected by the anticipated inflation rate, the public deficit/GDP ratio, and the U.S. federal funds rate.

Tytell and Wei (2005) studied the effect of dynamic policies on financial globalization using both monetary and fiscal policies. They estimated a simultaneous equation between inflation and budget deficit using transmission matrix approach. This was done to correct the endogeneity problem in the model. Their study concluded that financial globalization can stimulate countries to pursue lower inflation rates but could not reduce the budget deficit. As a result, the strength of the discipline effect varies across different public policy.

Iya et al. (2014) studied the effect of fiscal shortfall on the Nigerian economy from 1981 to 2009 using causality and multiple regression to analyse their data. Their finding showed that there existed one-direction causality between real GDP and exchange rate from the tool of causality. The multiple regression result indicated that exchange rate, interest rate and government fiscal deficit have direct impact on economic growth in Nigeria.

Navaratnam and Mayandy (2016) investigated the impact of fiscal deficit on economic growth in some selected South Asian countries. They employed annual data between 1980 and 2014 with cointegration and granger causality test as tools to examine the dynamic association within the variables. Findings from their study showed that fiscal shortfall has inverse effect on economic growth in South Asian, but Nepal has a direct impact. This could be a function of degree of development in the economy.

In Nigeria, Ajogbeje, Adeniyi and Egwikhide (2018), examined the impact of trilemma policy path on interest rate using a quarterly which spanned between 1971 and 2017 in Nigeria. The study employed both long and short run ARDL estimation technique. The outcome of their study showed that capital mobility has significant effect on interest rate while exchange rate and independent monetary policy do not affect interest rate independently; they jointly have significant impact on interest rate through their interaction with external reserves.

\section{Methodology}

Due to few papers on this topic in economic literature, very few methods have been used so far. Some used OLS; Cointegration method which perhaps only analyses the long run relationship; VAR and VECM which have issues with theory and equality of lag periods of explanatory variables which in real world situations, may not be obtainable. Others used SVAR which is mostly used for relationship with more than six variables; ARDL and its Error Correction. This study employed Cointegration and ECM because the techniques of analysis are backed with economic theory and take care of disaggregated impact/effect of both the short run and long run. Forecasted variance decomposition was also engaged to decompose the dependent variable.

The study started with a preliminary stationary test because of the fear of falling into spurious issues. Since Phillip Peron (PP) and Augmented-Dickey Fuller (ADF) test results are usually moving toward the same direction, only the ADF was employed to test for 
unit root in the data. The stability of the ECM, which is paramount, was also engaged alongside the residual tests.

\subsection{Model Specification}

FDI was made a proxy of capital inflow into Nigeria, and stood in as the dependent variable, while budget deficit, foreign loan and domestic loan were proxy of fiscal effect and were made the explanatory variables. Hence, the study adapted the model of Nwaeze, Kalu and Tamuno (2017) as:

$$
F D I=f(B D, F L, D L)
$$

The equation 1 is presented in a mathematical model as

$$
\mathrm{FDI}=\delta_{0}+\delta_{1} \mathrm{BD}+\delta_{2} \mathrm{FL}+\delta_{3} \mathrm{DL}
$$

Since the model might have left some other variables which could affect the dependent variable (FDI) but not captured in the model, we represented these other variables as error term and converted equation 2 into an econometric model as:

Where,

$$
\mathrm{FDI}=\delta_{0}+\delta_{1} \mathrm{BD}+\delta_{2} \mathrm{FL}+\delta_{3} \mathrm{DL}+\mathrm{u}_{\mathrm{i}}
$$

FDI Foreign direct investment

BD Federal government budget deficit

FL Foreign loan obtained.

DL Domestic loan obtained

$\mathrm{u}_{i} \quad$ Error term, which represents all other necessary variables not captured in the model.

The study could not log the variables because of the fear of loss of observations with negative signs and thus, reducing the potency and chance to employ cointegration and error correction techniques. Hence, capital flow into Nigeria was represented by foreign direct investment (FDI), the fiscal effects were represented by budget deficit (BD), foreign loan (FL) and domestic loan (DL) which represented the explanatory variables.

Our a priori expectation was that, when budget deficit increases, the government obtains loan from both international and local investors. The action, which will lead to rise in interest rate, will reduce the private investment because the cost of investment would go high. Thus, there exists an indirect impact.

\subsection{Data Issue}

Annual time series data covering the period from 1970 to 2011 were sourced from the CBN Statistical Bulletin 2017 series, which made us have 41 observations in all. The choice of our data set being annual was because the variables used were annual in nature in most economies. The choice of 2011 was because the federal government did not obtain foreign loan, according to CBN (2017), from 2012 to 2016. As such, there would be statistical issues if used like that and the reliability of our results would be at stake. 


\section{RESEARCH FINDINGS}

\subsection{Results of Unit Root Test}

Table 1 presents the results of unit root test which employed ADF only. From the results, it shows that at level (0), all the variables display presence of trend and thus are non-stationary. At first difference (1), only FDI and BD are stationary while FL and DL are stationary at second difference (2), all at $1 \%$ level of significance.

Table 1 ADF Unit Root Test

\begin{tabular}{lcccccc}
\hline Variable & At Level & Prob. & At $1^{\text {st }}$ Diff & Prob. & At 2 ${ }^{\text {nd }}$ Diff & Prob. \\
\hline FDI & -1.4853 & 0.5323 & $-8.7212^{* * *}$ & 0.0000 & - & - \\
BD & 4.3700 & 1.0000 & $-5.7567^{* * *}$ & 0.0000 & - & - \\
FL & 4.9455 & 1.0000 & 0.2078 & 0.9697 & $-5.1808^{* * *}$ & 0.0001 \\
DL & 3.4950 & 1.0000 & -0.4863 & 0.8836 & $-8.2705^{* * *}$ & 0.0000 \\
\hline
\end{tabular}

Indicates significance at $1 \%$ level

Source: Author's extract from E-views 9

Table 2 showcases results of the lag order criteria of the model. From the table, all five criteria select 5-lag as the best lag selection for our model. However, because of insufficient data to use this selected lag period, we make use of 2-lag periods as automatically selected by Johenson cointegration test.

\subsection{Result of Lag Selection Order}

Table 2 Lag Selection Order

\begin{tabular}{ccccccc}
\hline Lag & LogL & LR & FPE & AIC & SC & HQ \\
\hline 0 & -1348.192 & NA & $4.24 \mathrm{e}+28$ & 77.26812 & 77.44587 & 77.32948 \\
1 & -1299.334 & 83.75735 & $6.53 \mathrm{e}+27$ & 75.39049 & 76.27926 & 75.69729 \\
2 & -1263.347 & 53.46631 & $2.17 \mathrm{e}+27$ & 74.24838 & 75.84817 & 74.80063 \\
3 & -1217.212 & 57.99838 & $4.29 \mathrm{e}+26$ & 72.52638 & 74.83718 & 73.32406 \\
4 & -1188.431 & 29.60322 & $2.55 \mathrm{e}+26$ & 71.79604 & 74.81786 & 72.83917 \\
5 & -1150.352 & $30.46267^{*}$ & $1.06 \mathrm{e}+26^{*}$ & $70.53442^{*}$ & $74.26725^{*}$ & $71.82299^{*}$ \\
\hline
\end{tabular}

indicates lag order selected by the criterion

LR: sequential modified LR test statistic (each test at $5 \%$ level)

FPE: Final prediction error

AIC: Akaike information criterion

SC: Schwarz information criterion

HQ: Hannan-Quinn information criterion

Source: Author's extract from E-views 9

\subsection{Results of Cointegration Test}

Tables 3 and 4 present the Johenson cointegration test. The Tables show the Trace and Maximum-Eigen statistics, both of which indicate 2 cointegrating equations at 5\% level of significance as the Mackinnon-Haug-Michelis (1999) p-values indicate. By implication, it is above the minimum of at least one, meaning that there is existence of long run relationship in the model. Hence, the model has satisfied the precondition for employing the ECM. 
Table 3 Cointegration: Rank Test (Trace)

\begin{tabular}{|c|c|c|c|c|}
\hline $\begin{array}{l}\text { Hypotheised No. of } \\
\text { CE(s) }\end{array}$ & Eignvalue & $\begin{array}{c}\text { Trace } \\
\text { Stat }\end{array}$ & $\begin{array}{c}0.05 \\
\text { Critical Value }\end{array}$ & Prob. \\
\hline None ${ }^{*}$ & 0.921346 & 130.3645 & 47.85613 & 0.0000 \\
\hline At most $1^{*}$ & 0.454385 & 36.28446 & 29.79707 & 0.0078 \\
\hline At most 2 & 0.232021 & 13.86833 & 15.49471 & 0.0866 \\
\hline At most $3^{*}$ & 0.104907 & 4.100606 & 3.841466 & 0.0429 \\
\hline
\end{tabular}

Table 4 Cointegration Rank Test (Max-Eigenvalue)

\begin{tabular}{lcccc}
\hline $\begin{array}{l}\text { Hypotheised No. } \\
\text { of CE(s) }\end{array}$ & Eignvalue & $\begin{array}{c}\text { Max-Eigen } \\
\text { Stat }\end{array}$ & $\begin{array}{c}0.05 \\
\text { Critical Value }\end{array}$ & Prob. \\
\hline None $^{*}$ & 0.921346 & 94.07999 & 27.58434 & 0.0000 \\
At most 1 & 0.454385 & 22.41614 & 21.13162 & 0.0328 \\
At most 2 & 0.232021 & 9.767721 & 14.26460 & 0.2276 \\
At most 3 & 0.104907 & 4.100606 & 3.841466 & 0.0429 \\
\hline
\end{tabular}

MacKinnon-Haug-Michelis (1999) p-values

Source: Author's extract from E-views 9

\subsection{Results of Short run Impact and ECM Coefficients}

Table 5 showcases the findings of short run impact and ECM coefficient. The Table shows that, in the short run period, one and two-lag periods of FDI have negative impact on present FDI and the impacts are both significant as their standard errors $(0.121$ and $0.138)$ and t-statistics (-6.519 and -2.424) show. The BD in one and two-lag periods show a positive sign which are also significant, as the standard error shows and the t-statistics (6.39 and 6.16) shows that they are significant at $1 \%$ level. In essence, a 1 unit increase in BD, on the average, leads to 36 units (one-lag) and 14 units (two-lag) increase in FDI.

Table 5 Short run Impact and ECM Coefficients

\begin{tabular}{lccc}
\hline Variable & Coefficient & Standard Error & t-Stat \\
\hline D(DFDI(-1)) & -0.789896 & 0.12118 & -6.51854 \\
D(DFDI(-2)) & -0.334069 & 0.13782 & -2.42392 \\
D(DDBD(-1)) & 36441807 & 5698750 & 6.39470 \\
D(DDBD(-2)) & 13571038 & 2203958 & 6.15757 \\
D(DDL(-1)) & -2958273. & 1739875 & -1.70028 \\
D(DDL(-2)) & 6875330. & 2687115 & 2.55863 \\
D(DFL(-1)) & -22121653 & $1.6 E+07$ & -1.37584 \\
D(DFL(-2)) & -9054654. & 1.6 E+07 & -0.56744 \\
\hline ECM(-1) & -0.532639 & 0.08002 & -6.65608 \\
$\mathrm{R}^{2}$ & 0.892750 & & \\
$\mathrm{R}^{2}$ Adjusted & 0.857000 & & \\
\hline
\end{tabular}

The FL (foreign loan) in both periods (one-lag and two-lag) shows a negative impact on FDI, meaning that, a 1 unit increase in FL, on the average, will lead to 22 units and 9 units 
reduction in FDI in one-lag and two-lag periods respectively. However, the impacts in both periods are not significant, even at $10 \%$ levels as the t-statistics (-1.38 and 0.567$)$ indicate.

Still on Table 5, DL, in one-lag period, shows a negative and significant impact at $10 \%$ level of significance, as the t-value (-1.70) indicates, meaning that, 1 unit increase in DL, on average, leads to 2.96 unit decrease in FDI. However, for two-lag period, there exists a positive and significant impact on FDI. The significance is at 5\% level as the t-statistics (2.56) indicates. The coefficient of ECM (-0.533) shows the correct negative sign and an average speed of adjustment. In essence, about $53 \%$ is the adjustment path between the short and long run periods. The $\mathrm{R}^{2}$ indicates that about $89 \%$ of the variation in FDI is explained by the explanatory variables in the model which is quite high. The $\mathrm{R}^{2}$ adjusted, which serves as a penalty for adding more explanatory variables, shows about $86 \%$, very close to the $\mathrm{R}^{2}$, meaning that, there is no redundancy in the explanatory variables.

\subsection{Results of Long Run Coefficient}

Table 6 Long Run Coefficient

\begin{tabular}{lccc}
\hline \multicolumn{1}{c}{ Variable } & Coefficient & Standard Error & t-Stat \\
DFDI(-1) & 1.000000 & & \\
DDBD(-1) & 90321707 & 5245823 & 17.2178 \\
DDL(-1) & -34525662 & 3193914 & -10.8098 \\
DFL(-1) & -65648099 & $2.7 \mathrm{E}+07$ & -2.40330 \\
\hline \multicolumn{4}{c}{ Source:Author's extract from E-views 9 }
\end{tabular}

Table 6 presents the results of long run coefficients of the model. On the Table, BD has positive and significant effect on the FDI. A unit increase in BD, on average, leads to 90 units increase in FDI and it is quite significant at $1 \%$ level as the t-statistics (17.22) indicates. The FL and DL both have negative impact on FDI in the long run. Therefore, a unit increase in FL and DL, on the average, will lead to 66 and 35 units reduction in FDI and these impacts are significant at $5 \%$ and $1 \%$ levels, as their t-statistics (-2.4 and -10.8) indicate.

Figure 1 presents the stability check result using inverse roots of autoregressive characteristic polynomial. From the result, since the condition for Stability of our ECM result is that the dots should converge within the circle and none of the dots should be outside, then we conclude that our data, model and variables are stable as evident in figure 1 .

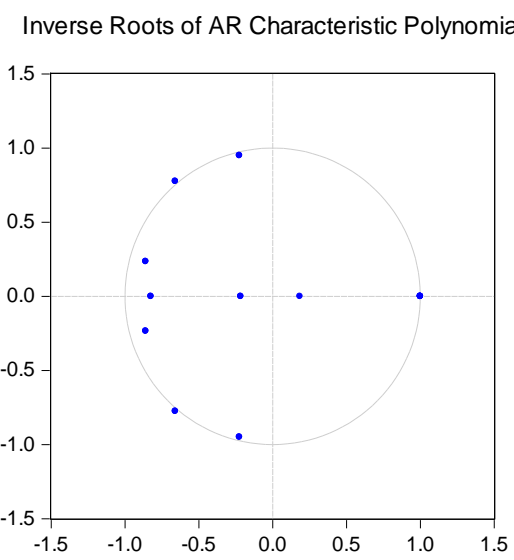

Fig. 1 Stability Check

Source: Author's extract from E-views 9

\subsection{Results of Forecasted Variance Decomposition}

Table 7 showcases the results of forecasted variance decomposition of FDI within 10 periods (years). From the table, in period 1, all the variances in FDI are explained by its own innovative shocks only. At period 2, only about $56 \%$ is explained by itself while $24 \%$, 
$19 \%$ and $1 \%$ are explained by BD, DL and FL respectively. The percentage variance of BD continues to increase up to the 10th period (24-30\%), meaning that, BD has a very powerful innovation in explaining changes in FDI. The impact of the innovations of DL and FL are also incremental but end on the $8^{\text {th }}$ period before declining. The percentage of FL in forecasting FDI, all through, is not more than $3 \%$ while the $\mathrm{BD}$ and DL have two-digit cause of variation.

Table 7 Forecasted Variance Decomposition

\begin{tabular}{cccccc}
\hline $\begin{array}{c}\text { Variance Decomposition } \\
\text { of FDI Periods }\end{array}$ & S.E. & DFDI & DDBD & DDL & DFL \\
\hline 1 & $6.08 \mathrm{E}+08$ & 100.0000 & 0.000000 & 0.000000 & 0.000000 \\
2 & $8.31 \mathrm{E}+08$ & 55.71319 & 23.86799 & 19.40722 & 1.011596 \\
3 & $8.94 \mathrm{E}+08$ & 50.17710 & 26.86050 & 22.06134 & 0.901062 \\
4 & $9.80 \mathrm{E}+08$ & 55.93368 & 22.42845 & 18.64530 & 2.992562 \\
5 & $1.11 \mathrm{E}+09$ & 54.30098 & 18.53903 & 24.82771 & 2.332284 \\
6 & $1.22 \mathrm{E}+09$ & 44.77193 & 29.04619 & 24.17136 & 2.010526 \\
7 & $1.36 \mathrm{E}+09$ & 49.53903 & 24.13955 & 24.26994 & 2.051479 \\
8 & $1.37 \mathrm{E}+09$ & 48.31264 & 24.90136 & 24.56313 & 2.222862 \\
9 & $1.59 \mathrm{E}+09$ & 48.26415 & 28.79505 & 21.28363 & 1.657159 \\
10 & $1.61 \mathrm{E}+09$ & 47.15410 & 30.32132 & 20.70525 & 1.819338 \\
\hline
\end{tabular}

Source: Author's extract from E-views 9

\subsection{Results of Diagnostic Check}

Lastly, Table 8 presents results of the diagnostic check on the error term in our model. All three tests used to check the assumptions of our error terms- normal distribution; no serial correlation; and no conditional heteroscedasticity- show acceptance of the null hypotheses. Jarque-Bera statistics $(0.3536)$ shows that we accept the null hypothesis that the distributions are normal, as evident from the probability (0.8379). The Langrage Multiplier (21.4405) shows that, we accept the $\mathrm{H}_{0}$, that there is no serial correlation as indicated in the probability (0.1622). Then the White (Chi-sq) test (202.178) means we accept that there is no conditional heteroscedasticity as shown in its probability $(0.1233)$. Hence our analysis is reliable, stable and inferences could be drawn from its results.

Table 8 Diagnostic Check

\begin{tabular}{llrc}
\hline Test & Null Hypothesis $\left(\mathrm{H}_{0}\right)$ & t-Statistic & Prob. \\
\hline Jarque-Bera (JB) & There is a normal distribution & 0.3536 & 0.8379 \\
Langrage Multiplier (LM) & No serial correlation & 21.4405 & 0.1622 \\
White (CH-sq) & No conditional heteroscedasticity & 202.1784 & 0.1233 \\
\hline & Source: Author's extract from E-views 9 & &
\end{tabular}

\subsection{Discussion of Result Findings and Implication of Findings}

The first objective of this study was to investigate whether budget deficit crowds out capital inflow using FDI as proxy. The ECM analysis showed that in both the short and long run, BD (budget deficit) does not crowd out but rather crowd in FDI as BD had a positive and significant impact on FDI. This is in line with the studies of Hussain and Haque (2016 and 2017) and in contrast with the work of Navaratnam and Mayandy (2016). 
The second objective was to examine the impact of fiscal borrowing on cash inflow into Nigeria. Our findings revealed that, in the short run, domestic borrowing (DL) averagely had positive and significant impact on FDI, since when the government borrows through selling of bonds within the country, it makes domestic investors have fewer funds to invest and thus, foreign investors would be encouraged to pump in more funds into the economy in the short run. However, in the long run, the impact of DL has negative and significant impact on FDI. This means that, in the long run, the government domestic borrowing will crowd out FDI in Nigeria.

Lastly, our objective was to determine the impact of foreign borrowing (FL) on FDI in Nigeria. Our results showed that, in both short run funds and long run period, foreign borrowings have negative and significant impact on foreign direct investment, and hence, foreign borrowing of the Nigerian government crowds out foreign direct investment (FDI). The speed of adjustment back to equilibrium, as indicated by the ECM analysis, showed that the explanatory variables have an average capacity to adjust FDI significantly.

The result of variance decomposition indicated that domestic borrowing had more powers in predicting changes in FDI than foreign borrowing, and that could be the main reason why Nigerian government has stopped borrowing from foreign source since 2012. It is also evident that budget deficit had more predictive capacity to explain volatility in FDI.

The main implication of our finding is that incurring deficit in Nigeria will crowd out foreign direct investment in both the short run and long run periods. In the short run, government borrowing from foreign source improves foreign direct investment but discourages it in the long run. Borrowing from domestic source through bonds has negative impact on foreign direct investment in both short and long run periods.

\section{CONCLUSION AND RECOMMENDATIONS}

The study investigated the effect of fiscal policy in crowding out capital inflows in Nigeria using annual data between 1970 and 2011 by making use of foreign direct investment (FDI) as proxy to capital inflows into Nigeria, budget deficit (BD), foreign borrowing (FL) and domestic borrowing (DL) as proxies to fiscal policy. FDI was made the dependent variable, and BD, FL and DL, the explanatory variables. The study first removed trends in the time series data used, with the aid of ADF only, then employed Johenson cointegration and ECM technique to analyse the data and supported it with forecasted variance decomposition tool. Afterwards, stability and diagnostic test were carried out to ascertain the credibility and reliability of the data and model employed.

Our finding showed that in both the short and long run, BD (budget deficit) does not crowd out but rather crowd in FDI as BD had a positive and significant impact on FDI. Our result revealed that, in the short run, domestic borrowing (DL) averagely had positive and significant impact on FDI. However, in the long run, the impact of DL has negative and significant impact on FDI. Moreover, our results showed that, in both short run funds and long run period, foreign borrowings have negative and significant impact on foreign direct investment, and hence, foreign borrowing of the Nigerian government crowds out foreign direct investment (FDI). The speed of adjustment back to equilibrium as indicated by the ECM analysis showed that the explanatory variables have an average capacity to adjust FDI significantly. 
Finally, domestic borrowing had more powers in predicting changes in FDI than foreign borrowing and that could be the main reason why Nigerian government has stopped borrowing from foreign source since 2012. It is also evident that budget deficit had more predictive capacity to explain volatility in FDI.

The study therefore, recommends that, the government of Nigeria could try to be aware of the implication of its fiscal policy in running a budget deficit and making proper decision in sourcing for funds to finance the deficit. Foreign borrowing is less expensive in financing budget deficit as it will not crowd out private investment per se, so the government could give preference to this source. More so, the government should try to minimise or even do without the deficit because of the implications inherent in it.

\section{REFERENCES}

Ajogbeje, A., Adeniyi, K., \& Egwikhide, F. O. (2018). Policy Trilemma and Interest Rate Behaviour in Nigeria. Central Bank of Nigeria Journal of Applied Statistics 9(2), 17-41.

Barro, R. (1989). The Ricardian Approach to Budget Deficits. Journal of Economic Perspectives, 3(2), $37-54$.

Mankiw, N. G (2003). Macroeconomics. 5th Ed. New York: Worth.

Bhaduri, S. (2002). Macroeconomic Theory. New Central Book Agency Ltd. Calcuta.

Central Bank of Nigeria (2017). Statistical Bulletin Vol. 28, December

Fleming, J. M. (1962). Domestic Financial Policy under Fixed and under Floating Exchange Rates. IMF Staff Papers, 9, 369-379.

Hussain, M., \& Haque, M. (2016). Foreign Direct Investment, Export and Economic Growth: An Empirical Analysis for Bangladesh. Economies 4. Available online: https://www.mdpi.com/2227-7099/4/2/7/pdf (accessed on 31 May 2017).

Han, P. (2014). Effects of Fiscal Policy under Different Capital Mobility in China. Accounting and Finance Research, 3(1). 111-113.

Hussain, M., \& Haque, M. (2017). Empirical Analysis of the Relationship between Money Supply and Per Capita GDP Growth Rate in Bangladesh. Journal of Advances in Economics and Finance (JAEF), 2, 54-66.

Hsing, Y. (2005). Application of the IS-MP-IA Model to the German Economy and Policy Implications. Economics Bulletin, 15(5), 1-10

Iya, I. B., Aminu, U., \& Gabdo, A. Y. (2014). An Empirical Analysis of the Effects of Fiscal Deficits on Economic Growth in Nigeria. International Journal of Emerging Technology and Advanced Engineering, 4(8), 1-9.

Jhingan, M. L. (2004). Macroeconomics. New Delhi, $12^{\text {th }}$ ed. Nisha Enterprise.

Keynes, J. M. (1936). The General Theory of Employment, Interest and Money. London:Macmillan.

MacKinnon, J. G., Haug, A. A., \& Michelis, L. (1999). Numerical distribution functions of likelihood ratio tests for cointegration. Journal of Applied Econometrics, 14, 563-577.

Mundell, R. A. (1963). Capital Mobility and Stabilization Policy under Fixed and Flexible exchange rates. Canadian Journal of Economics and Political Science/Revue Canadienne de economiques et science politique, 29(4), 475-485

Navaratnam, R., \& Mayandy, K. (2016). Causal Nexus between Fiscal Deficit and Economic Growth: Empirical evidence from South Asia. International Journal for Innovation Education and Research, 8, 1-19.

Nwaeze, N. C., Kalu, I. E., \& Tamuno S. O. (2017). Exchange Rate Volatility and Fiscal Deficit in Nigeria: Any Causality? (1970-2016). Greener Journal of Economics and Accountancy, 6(3), 82-95.

Pierdzioch, C. (2004). Capital Mobility and the Effectiveness of Fiscal Policy in Open Economies. Journal of Macroeconomics, 26(3), 465-479.

Pugel, T. A. (2012). International Economics. McGraw-HillIwin. New York. $15^{\text {th }}$ Ed.

Rodriguez, C. A. (1979). Short-and Long-run Effects of Monetary and Fiscal Policies under Flexible exchange rates and perfect capital mobility. The American Economic Review, 69(1), 176-182.

Rose, A. K. (1994). Exchange Rate Volatility, Monetary Policy, and Capital Mobility: Empirical Evidence on the Holy Trinity (No. w4630). National Bureau of Economic Research.

Tytell, I., \& Wei, S. J. (2012). Global Capital Flows and National Policy Choices. IMF "Foreign direct investment, net inflows (BoP, current US\$) | Data | Table". Data.worldbank.org. Retrieved 17 November 2012.

Yeung-Nan, S. (2015). Capital Mobility and Fiscal Policy under Flexible Exchange Rates: An Application of Romer's IS-MP Model. American Journal of Business, Economics and Management, 3(3), 141-144. 


\section{EFEKAT ISTISKIVANJA FISKALNE POLITIKE NA KAPITALNE PRILIVE U NIGERIJI}

Rad je istraživao efekte fiskalne politike na istiskivanje kapitalnih priliva u Nigeriji koristeći godišnje podatke između 1970. i 2011. upotrebom direktnih stranih investicija (SDI) kao pokazatelja priliva kapitala koji predstavljaju zavisnu varijablu, dok su budžetski deficit (BD), strana zaduživanja (SZ) i domaća zaduživanja (DZ) kao pokazatelji fiskalne politike postavljeni kao objašnjavajuće promenljive. Korišćena je kointegracija i ECM tehnika. Naši nalazi su pokazali da i kratkoročno $i$ dugoročno BD ne istiskuje već čini deo SDI. Kratkoročno, DZ imaju snačajan pozitivni uticaj na SDI. Međutim, dugoročno, DZ ima značajan negativni uticaj na SDI. Osim toga, i kratkoročno i dugoročno, SZ ima značajnno negativni uticaj na SDI, prema tome, SZ istiskuje SDI. Brzina prilagođavanja vraćanju ravnoteži pokazala je da objašnjavajuće varijabile imaju sposobnost da značajno prilagode SDI. Istraživanje preporučuje da vlada može da pokuša da bude svesna implikacija na svoju fiskalnu politiku u vođenju budžetskog deficita i donošenju pravih odluka pri traženju fondova za finansiranje deficita. Strano zaduživanje je manje skupo u finansiranju budžetskog deficit, te ako vlada mora da pozajmljuje, trebalo bi da daje prednost ovom izvoru. Generalno, vlada bi trebalo da smanji deficit zbog implikacija koje su mu inherentne.

Ključne reči: SDI, budžetski deficit, inostrani zajmovi, domaći zajmovi 